\title{
Myths and misconceptions regarding contraception in the urban poor community in Jamshedpur, India
}

\section{Pushpa Tiwari*}

Tata Steel Family Initiatives Foundation, Tata Steel, Jamshedpur, Jharkhand, India

Received: 23 June 2018

Accepted: 24 July 2018

\section{*Correspondence:}

Dr. Pushpa Tiwari,

E-mail: pushpa.tiwari@tatasteel.com

Copyright: () the author(s), publisher and licensee Medip Academy. This is an open-access article distributed under the terms of the Creative Commons Attribution Non-Commercial License, which permits unrestricted non-commercial use, distribution, and reproduction in any medium, provided the original work is properly cited.

\begin{abstract}
Background: Family planning, a basic human right endorsed by the United Nations, allows everyone to decide the number, spacing and timing of their children. This leads to fewer complications related to pregnancy and childbirth, improves overall health.

Despite the obvious benefits, because of deeply rooted myths and misconceptions, they do not access these services. Methods: Study was conducted in 10 Maternal and Child Health centers run by Tata Steel Family Initiatives Foundation in and around Jamshedpur in Jharkhand, India. The study is based on primary quantitative data. Data collection was by interviewing the respondents using a questionnaire.

Results: A total of 500 respondents were interviewed. Out of 500 respondents 392 were women and 108 were men. The concept of family planning was well known. $99 \%$ women while $100 \%$ men had heard about family planning. Only $49 \%$ women and $45 \%$ men had correct knowledge regarding spacing between two children. $78 \%$ women and men had correct knowledge about dual benefits of condom use. $63 \%$ women and $64 \%$ men feel that $\mathrm{Cu} \mathrm{T}$ causes backache and pain abdomen, hence they avoid using it. 54\% women and 51\% men do not like OCP as a method of family planning as it is difficult to take it daily. Around $45 \%$ women and men were afraid regarding Tubectomy/ LTT. More women (41\%) than men (38\%) think that NSV causes weakness. Again, more women (36\%) than men (34\%) think that NSV decrease capacity to do heavy work.

Conclusions: Results are showing that only knowledge about contraception is not enough to increase usage. Behaviour change communication activities are needed to provide accurate information to dispel common myths and misconceptions about modern contraceptives.
\end{abstract}

Keywords: Behaviour change communication, Contraception, Myths and misconceptions

\section{INTRODUCTION}

Family planning, a basic human right endorsed by the United Nations, allows couples and individuals to decide freely and responsibly the number, spacing and timing of their children. ${ }^{1}$

Family planning is central to gender equality and women's empowerment, and it is a key factor in reducing poverty. Yet in developing regions, some 214 million women who want to avoid pregnancy are not using safe and effective family planning methods. ${ }^{2}$

The Sustainable Development Goals target 3.7 specifically recognises the importance of information and education: "By 2030, ensure universal access to sexual and reproductive health care services, including for family planning, information and education, and the 
integration of reproductive health into national strategies and programs." 3

India has traversed a long and arduous path since launching the first ever Family Planning programme in the world in 1952. The programme has further evolved from a targeted approach to a target free approach and has now been anointed as a critical intervention to reduce maternal and child mortality and morbidity beyond a simple strategy for achieving population stabilization. India, the second most populous country of the world, harbours $17.5 \%$ of the world's population in only $2.4 \%$ of the global land mass. Therefore, large population size of India not only impacts its own but also the global health indicators. $^{4}$

Census 2011 India has registered decadal growth rate to be $17.64 \%$ while it was $21.54 \%$ in the census 2001 . Among the total decadal growth rate, the rural areas of India grew at $12.18 \%$ whereas, the urban areas of the country grew at the rate of $31.80 \%$ in the last census decade. The state of Jharkhand state in India has shown decadal growth rate of $22.3 \%$ in the last census decade. ${ }^{5}$

One of the goals enunciated in its National Population Policy 2000, was to stabilize the population at a level consistent with the requirement of national economy. ${ }^{6}$ However, this goal could not be achieved in the stipulated time. It was realized that without increasing use and access to contraceptives it would be difficult to impact the prevailing high maternal, infant and child mortality substantially. In 2012 the 'London Summit on Family Planning' was held to bring back the focus on family planning globally.

Purpose of this study is to explore the myths and misconceptions affecting utilization of FP among urban poor in Jamshedpur.

Myths and misconceptions about methods can spread very easily in the community.

Understanding why people do not use family planning is critical to increase contraceptive use.

\section{METHODS}

Study was conducted in 10 Maternal and Child Health centers run by Tata Steel Family Initiatives Foundation free of cost in and around Jamshedpur city in Jharkhand state in India. These centers provide services to urban poor from slums. This study was conducted from February 2018 to March 2018.

Simple random sampling method was used for sampling. Total 500 interviews were conducted, out of which 392 were women of reproductive age group and 108 were men. The study is based on primary data. Consent was taken from the women and men who were enrolled in the study. All the women and men who had given consent were interviewed based on a predesigned questionnaire.

\section{Inclusion criteria}

- For women was that she should not be pregnant at the time of interview

- For men was that his wife should not be pregnant at the time of interview.

\section{Exclusion criteria}

- Those women who were pregnant at the time of interview

- Women who were infertile.

Data analysis was done using Microsoft excel.

\section{RESULTS}

A total of 500 respondents were interviewed. Out of 500 respondents 392 were women and 108 were men.

dd

Table 1: Awareness and benefits of family planning.

\begin{tabular}{|c|c|c|c|c|c|}
\hline \multicolumn{6}{|c|}{ Respondents who have heard about F. P. } \\
\hline & $\begin{array}{l}\text { Women } \\
(n=392)\end{array}$ & $\%$ & $\begin{array}{l}\text { Men } \\
(n=108)\end{array}$ & $\%$ & $\begin{array}{l}\text { Total } \\
\%\end{array}$ \\
\hline Yes & 389 & 99.23 & 108 & 100 & 99.40 \\
\hline No & 3 & 0.77 & 0 & 0.00 & 0.60 \\
\hline \multicolumn{6}{|c|}{ Knowledge regarding spacing between two children } \\
\hline 2 yrs. & 15 & 3.83 & 6 & 5.50 & 4.19 \\
\hline 3 yrs. & 194 & 49.49 & 50 & 45.87 & 48.70 \\
\hline 4 yrs. & 46 & 11.73 & 16 & 14.68 & 12.38 \\
\hline 5 yrs. or & 137 & 34.95 & 37 & 33.94 & 73 \\
\hline
\end{tabular}

Knowledge about benefits of family planning

\begin{tabular}{|c|c|c|c|c|c|}
\hline $\begin{array}{l}\text { keeps both } \\
\text { mother and } \\
\text { baby healthy }\end{array}$ & 190 & 48.47 & 51 & 48.11 & 48.39 \\
\hline $\begin{array}{l}\text { Reduces } \\
\text { maternal } \\
\text { and infant } \\
\text { mortality }\end{array}$ & 0 & 0.00 & 0 & 0.00 & 0.00 \\
\hline $\begin{array}{l}\text { Prevents } \\
\text { malnutrition }\end{array}$ & 2 & 0.51 & 0 & 0.00 & 0.40 \\
\hline $\begin{array}{l}\text { All are } \\
\text { correct }\end{array}$ & 200 & $\begin{array}{l}51.0 \\
2\end{array}$ & 55 & 51.89 & 51.20 \\
\hline
\end{tabular}

NR: Not responded to this question

Table 1 shows that the concept of family planning was well known among the community. 99\% women while $100 \%$ men had heard about family planning but only 49 $\%$ women and $46 \%$ men had correct knowledge regarding spacing between two children. Only $51 \%$ respondents had correct knowledge regarding benefits of family planning. (Table 1). Table 2 shows that in our study $78 \%$ women and men had correct knowledge about dual benefits of 
condom use which is very important for prevention of RTI/STI and HIV/AIDS (Table 2).

Table 2: Knowledge about benefits of using condom.

\begin{tabular}{|lcclll|}
\hline & $\begin{array}{c}\text { Women } \\
\mathrm{n=392}\end{array}$ & $\%$ & $\begin{array}{l}\text { Men } \\
\mathrm{n=108}\end{array}$ & $\%$ & $\begin{array}{l}\text { Total } \\
\%\end{array}$ \\
\hline $\begin{array}{l}\text { Prevention of } \\
\text { RTI/STI }\end{array}$ & 19 & 5.03 & 4 & 3.85 & 4.77 \\
$\begin{array}{l}\text { Preventing } \\
\text { pregnancy }\end{array}$ & 61 & 16.14 & 18 & 17.31 & 16.39 \\
$\begin{array}{l}\text { Both are } \\
\text { correct }\end{array}$ & 295 & 78.04 & 82 & 78.85 & 78.22 \\
\hline $\begin{array}{l}\text { None of them } \\
\text { is correct }\end{array}$ & 3 & 0.79 & 0 & 0.00 & 0.62 \\
\hline NR & 14 & - & 4 & - & - \\
\hline
\end{tabular}

NR: Not responded to this question
Table 3 shows various myths and misconceptions regarding temporary methods of family planning. Myths and misconceptions spread very easily in the community and discourage many potential or current users. $44 \%$ women and $41 \%$ men responded that condom tears which shows that correct method of using condom needs to be explained properly. $63 \%$ women and $64 \%$ men feel that $\mathrm{Cu} \mathrm{T}$ causes backache and pain abdomen, hence they avoid using it. This means that proper counselling is needed. 54\% women and 51\% men do not like OCP as a method of family planning as it is difficult to take it daily. This means that some method needs to be suggested to them for remembering to take it daily e.g. Putting a mark in the calendar after taking it, taking it at a fixed time, keeping the packet at a prominent visible place, putting an alarm (Table 3).

Table 3: Myths and misconceptions regarding temporary methods of family planning.

\begin{tabular}{|c|c|c|c|c|c|}
\hline \multicolumn{6}{|l|}{ Condom } \\
\hline & Women $(n=392)$ & $\%$ & $\operatorname{Men}(n=108)$ & $\%$ & Total \% \\
\hline Husband does not like it & 52 & 44.44 & 13 & 35.14 & 42.21 \\
\hline Condom tears & 51 & 43.59 & 15 & 40.54 & 42.86 \\
\hline Wife does not like it & 14 & 11.97 & 9 & 24.32 & 14.94 \\
\hline NR & 275 & & 71 & & \\
\hline \multicolumn{6}{|l|}{$\mathrm{Cu} \mathbf{T}$} \\
\hline $\mathrm{Cu} \mathrm{T}$ causes cancer & 31 & 10.92 & 9 & 13.85 & 11.46 \\
\hline Weight increases & 62 & 21.83 & 13 & 20.00 & 21.49 \\
\hline Weight decreases & 10 & 3.52 & 1 & 1.54 & 3.15 \\
\hline It causes backache, pain abdomen & 179 & 63.03 & 42 & 64.62 & 63.32 \\
\hline A \& D both & 2 & 0.70 & 0 & 0.00 & 0.57 \\
\hline NR & 108 & & 42 & & \\
\hline \multicolumn{6}{|l|}{ Combined oral contraceptive pills } \\
\hline Forget to take it daily & 153 & 53.87 & 43 & 51.19 & 53.26 \\
\hline Menstruation becomes irregular & 39 & 13.73 & 16 & 19.05 & 14.95 \\
\hline It causes nausea & 53 & 18.66 & 12 & 14.29 & 17.66 \\
\hline Weight increases & 37 & 13.03 & 13 & 15.48 & 13.59 \\
\hline A \& C Both & 1 & 0.35 & 0 & 0.00 & 0.27 \\
\hline B \& D Both & 1 & 0.35 & 0 & 0.00 & 0.27 \\
\hline NR & 108 & - & 24 & - & - \\
\hline
\end{tabular}

NR: Not responded to this question

Table 4: Myths and misconceptions regarding permanent methods of family planning.

\begin{tabular}{|c|c|c|c|c|c|}
\hline & Women $(n=392)$ & $\%$ & Men $(n=108)$ & $\%$ & Total \% \\
\hline \multicolumn{6}{|l|}{ Tubectomy/ LTT } \\
\hline Because of fear & 126 & 44.52 & 39 & 45.35 & 44.72 \\
\hline Family members do not want & 47 & 16.61 & 17 & 19.77 & 17.34 \\
\hline It causes weakness & 72 & 25.44 & 21 & 24.42 & 25.20 \\
\hline It causes obesity & 38 & 13.43 & 9 & 10.47 & 12.74 \\
\hline NR & 109 & - & 22 & - & - \\
\hline \multicolumn{6}{|l|}{ NSV } \\
\hline It causes weakness & 122 & 41.36 & 35 & 39.33 & 40.89 \\
\hline Decreases capacity to do heavy work & 107 & 36.27 & 31 & 34.83 & 35.94 \\
\hline It affects earning capacity & 31 & 10.51 & 10 & 11.24 & 10.68 \\
\hline It decreases libido & 35 & 11.86 & 13 & 14.61 & 12.50 \\
\hline NR & 97 & & 19 & & \\
\hline
\end{tabular}

NR: Not responded to this question 
Table 4 shows myths and misconceptions regarding permanent methods of family planning. Around $45 \%$ women and men were afraid regarding Tubectomy/ LTT which needs proper counselling. More women (41\%) than men (38\%) think that NSV causes weakness. Again, more women $(36 \%)$ than men $(34 \%)$ think that NSV decrease capacity to do heavy work. While men (12\%) more than women (10\%) feel that NSV affects earning capacity and again more men (15\%) than women $(12 \%)$ feel that NSV decreases libido (Table 4).

Table 5 shows that $98 \%$ women and $95 \%$ men had ever discussed family planning with their spouse. For the success of family planning, it is very important couples discuss it among themselves. Table 6 shows that $7 \%$ women and $4 \%$ men think that family planning is only the responsibility of women.

Table 7 shows that in our study only 32\% women and $37 \%$ men had education level above Std. 10. Out of total respondents $67 \%$ women and $93 \%$ men were Hindu while $31 \%$ women and $5.5 \%$ men were Muslims. 39\% respondents had only one living child, $41 \%$ had 2 children, $14 \%$ had 3 and $4 \%$ had more than three children.

Table 5: Ever discussed family planning with their spouse.

\begin{tabular}{|llllll|}
\hline & $\begin{array}{l}\text { Women } \\
(\mathrm{n}=392)\end{array}$ & $\%$ & $\begin{array}{l}\text { Men } \\
(\mathrm{n}=108)\end{array}$ & $\%$ & $\begin{array}{l}\text { Total } \\
\%\end{array}$ \\
\hline Yes & 380 & 97.94 & 97 & 95.10 & 97.35 \\
\hline No & 8 & 2.06 & 5 & 4.90 & 2.65 \\
\hline NR & 4 & - & 6 & - & - \\
\hline
\end{tabular}

NR: Not responded to this question

Table 6: Is family planning is only the responsibility of women.

\begin{tabular}{|llllll|}
\hline & $\begin{array}{l}\text { Women } \\
(\mathbf{n = 3 9 2 )})\end{array}$ & $\%$ & $\begin{array}{l}\text { Men } \\
(\mathbf{n = 1 0 8 )})\end{array}$ & $\begin{array}{l}\text { Total } \\
\%\end{array}$ \\
\hline Yes & 27 & 6.94 & 4 & 3.77 & 6.26 \\
\hline No & 362 & 93.06 & 102 & 96.23 & 93.74 \\
\hline NR & 3 & - & 2 & - & - \\
\hline
\end{tabular}

NR: Not responded to this question

Table 7: Education level, religion and no. of living children.

\begin{tabular}{|llllll|}
\hline Education level & Women $(\mathbf{n = 3 9 2 )}$ & \% & Men $(\mathbf{n = 1 0 8})$ & \% & Total \% \\
\hline Illiterate & 10 & 2.55 & 4 & 3.70 & 2.80 \\
\hline Primary (up to std. 5) & 34 & 8.67 & 4 & 3.70 & 7.60 \\
\hline Middle (up to std. 8) & 101 & 25.77 & 24 & 22.22 & 25.00 \\
\hline Matric pass (up to std. 10) & 120 & 30.61 & 35 & 32.41 & 31.00 \\
\hline Above matric pass (above std. 10) & 127 & 32.40 & 41 & 37.96 & 33.60 \\
\hline Religion & & & & 93.52 & 73.00 \\
\hline Hindu & 264 & 67.35 & 101 & 5.56 & 25.80 \\
\hline Muslim & 123 & 31.38 & 6 & 0.93 & 1.00 \\
\hline Sikh & 4 & 1.02 & 1 & 0.00 & 0.20 \\
\hline Christian & 1 & 0.26 & 0 & 49.07 \\
\hline No. of living children & & & & 39.00 \\
\hline 1 & 142 & 36.22 & 53 & 35.19 \\
\hline 2 & 167 & 42.60 & 38 & 41.00 \\
\hline 3 & 59 & 15.05 & 15 & 13.89 & 14.80 \\
\hline 4 & 20 & 5.10 & 1 & 0.93 \\
\hline 5 & 2 & 0.51 & 1 & 4.20 \\
\hline 6 & 1 & 0.26 & 0 & 0.93 \\
\hline 7 & 1 & 0.26 & 0 & 0.00 \\
\hline
\end{tabular}

\section{DISCUSSION}

Family planning, a basic human right endorsed by the United Nations, allows everyone to decide the number, spacing and timing of their children. This leads to fewer complications related to pregnancy and childbirth, improves overall health. Entire communities also benefit, as women who can access family planning can better provide for their existing children, from food to education to housing, thereby making a greater contribution to the economy. Despite the obvious benefits, because of deeply rooted myths and misconceptions, they do not access these services.

In the case of family planning, the difficult part is not convincing an individual that the service will be 
beneficial to them - in most communities women want to be able to plan their families. Cultural beliefs that prevent women from making their own decisions negatively impact the implementation of family planning services. Overcoming these barriers requires innovative approaches that are different from those implemented for other health care services. ${ }^{7}$

Results are showing that only knowledge about contraception is not enough to increase usage. Awareness programs are needed to provide accurate information to dispel common myths and misconceptions about modern contraceptives.

Families are required to be educated on family planning's role in ensuring pregnancies occur at the healthiest times in a woman's life. This helps avoid high-risk pregnancies.

For regular intake of oral contraceptive pills, some method needs to be suggested to them for remembering to take it daily e.g. Putting a mark in the calendar after taking it, taking it at a fixed time, keeping the packet at a prominent visible place, putting an alarm.

Behaviour change communication activities can help families understand that newborns and children are healthier with longer intervals between births. A key message is "after a live birth, wait at least 24 months before attempting a pregnancy. ${ }^{8}$ Too long intervals (>5 years) are also associated with adverse health outcomes.

\section{Myths and Misconceptions in other countries}

In a study conducted in Kenya, Nigeria, and Senegal, the three myths most commonly endorsed by women were "people who use contraceptives end up with health problems" (48-74\%), "contraceptives are dangerous to women's health" (47-72\%) and "contraceptives can harm your womb" (37-62\%). ${ }^{9}$ In a study conducted in Malawi, the result showed that 28 percent of women have never discussed family planning with their husbands, and 27 percent of men think that contraception is a "woman's business." $" 10$

In present study, it was found that $98 \%$ women and $95 \%$ men had ever discussed family planning with their spouse and $7 \%$ women and $4 \%$ men think that family planning is only the responsibility of women.

\section{Funding: No funding sources}

Conflict of interest: None declared

Ethical approval: The study was approved by the Institutional Ethics Committee

\section{REFERENCES}

1. The Guardian- Socio-cultural barriers to family planning. Available at https://www.theguardian.com/journalismcompetition /2011-theme-family-planning.

2. UNFPA- Family https://www.unfpa.org/family-planning

3. Global indicator framework for the Sustainable Development Goals and targets of the 2030 Agenda for Sustainable Development. Available at https://unstats.un.org/sdgs/indicators/indicators-list/

4. India Vision FP 2020

5. Decadal growth rate. Available at https://www.mapsofindia.com/census2011/decadalgrowth-rate.html.

6. National Population Policy 2000

7. Cultural Barriers to Family Planning- by Liz Fortier. Available https://www.girlsglobe.org/2013/11/14/culturalbarriers-to-family-planning/

8. HTSP 101- Everything you want to know about healthy timing and spacing of pregnancy. Available at: www.who.int/pmnch/topics/maternal/htsp101.pdf

9. Gueye A, Speizer IS, Corroon M, Okigbo CC. Belief in family planning myths at the individual and community levels and modern contraceptive use in urban Africa. Int Perspect Sexual Reprod Health. 2015Dec;41(4):191.

10. Gates annual report. Family planning improving the lives of women and their families around the world 2011 report.

Cite this article as: Tiwari P. Myths and misconceptions regarding contraception in the urban poor community in Jamshedpur, India

Int J Reprod Contracept Obstet Gynecol 2018;7:3659-63. 